\title{
Skin-to-skin contact and breastfeeding of newborns in a university hospital
}

\section{Paola Melo Camposa Helga Geremias Gouveiab Juliana Karine Rodrigues Strada ${ }^{a}$ Bruna Alibio Moraes ${ }^{a}$}

\section{How to cite this article:} Campos PM, Gouveia HG, Strada JKR, Moraes BA.Skin-to-skin contact and breastfeeding of newborns in a university hospital. Rev Gaúcha Enferm. 2020;41(esp):e20190154. doi: https://doi.org/10.1590/19831447.2020.20190154

\footnotetext{
a Universidade Federal do Rio Grande do Sul (UFRGS), Porto Alegre, Rio Grande do Sul, Brasil

- Universidade Federal do Rio Grande do Sul (UFRGS). Escola de Enfermagem. Departamento de Enfermagem Materno-Infantil. Porto Alegre, Rio Grande do Sul, Brasil.
}

\section{ABSTRACT}

Objective: To determine the prevalence of skin-to-skin contact (STSC) and breastfeeding (BF) stimulation, as well as the reasons for these practices not to be performed; to identify whether women were given information on these practices along the pre-natal monitoring.

Method: A cross-sectional study carried out in a university hospital with 586 women. Data collection was from February to September 2016. Data was collected from patient records and from a questionnaire. A descriptive analysis was performed.

Results: Immediately after birth, $60.1 \%$ of the newborns (NBs) had STSC, and $44.9 \%$ were stimulated to suck at the breast. After primary care, $24.1 \%$ had STSC, and $69.3 \%$ were stimulated to suck at the breast; $47.7 \%$ of the newborns did not have STSC due to their unfavorable clinical conditions; $79.2 \%$ of the women were not able to inform the reason why BF was not stimulated; $58.5 \%$ of the women had pre-natal guidance about STSC, and $90.8 \%$ about BF.

Conclusion: Both STSC and BF rates could be improved, in view of the benefits provided by these practices.

Keywords: Breastfeeding. Perinatal care. Mother-child relations. Obstetric nursing.

\section{RESUMO}

Objetivo: Determinar a prevalência do contato pele a pele (CPP) e do estímulo ao Aleitamento Materno (AM) e motivos da não realização dessas práticas; identificar se as mulheres receberam informações sobre essas práticas no pré-natal.

Método: Estudo transversal realizado em hospital universitário com 586 mulheres. A coleta de dados foi de fevereiro a setembro de 2016, em prontuários e por meio de questionário. Procedeu-se análise descritiva.

Resultados: Imediatamente ao nasciment0,60,1\% dos recém-nascidos (RN) realizaram (PP e 44,9\% foram estimulados a mamar. Após os primeiros cuidados,24,1\% fizeram CPP e 69,3\% foram estimulados a mamar;47,7\% não realizaram CPP por não apresentarem boas condições clínicas;79,2\% das mulheres não souberam informar o motivo do não estímulo ao AM;58,5\% mulheres receberam orientação no pré-natal sobre CPP e 90,8\% sobre AM.

Conclusão: Consideramos que há oportunidade de melhorias nas taxas de CPP e AM, tendo em vista os benefícios dessas práticas. Palavras-chave: Aleitamento materno. Assistência perinatal. Relação mãe-filho. Enfermagem obstétrica.

\section{RESUMEN}

Objetivo: Determinar la prevalencia del contacto piel con piel (CPP) y del estímulo a la lactancia materna (LM) y los motivos para no realizar estas prácticas; identificar si las mujeres recibieron información sobre las mismas durante el prenatal.

Método: Estudio transversal realizado en un hospital universitario con 586 mujeres. La recolección de datos se efectuó de febrero a septiembre de 2016. La recolección de datos se realizó en prontuarios y por medio de cuestionarios. Se procedió a un análisis descriptivo.

Resultados: Inmediatamente después del nacimiento, el 60,1\% de los recién nacidos (RN) tuvieron CPP y el 44,9\% fueron estimulados a mamar. Después de los primeros cuidados, el 24,1\% tuvieron CPP y el 69,3\% fueron estimulados a mamar; el 47,7\% de los RN no tuvieron CPP por no presentar buenas condiciones clínicas; el 79,2\% de las mujeres no supieron informar el motivo de la falta de estímulo para la LM; el 58,5\% de las mujeres recibieron orientación sobre CPP en el prenatal, y el 90,8\%, sobre LM.

Conclusión: Consideramos que hay oportunidad de mejoría en los índices de CPP y de LM, considerando los beneficios de estas prácticas.

Palabras clave: Lactancia materna. Atención perinatal. Relaciones madre-hijo. Enfermería obstétrica. 


\section{口 INTRODUCTION}

The implementation of good childbirth care practices is recommended by government initiatives to qualify care and to reduce the use of interventions deemed unnecessary.

The Child Friendly Hospital Initiative (Iniciativa Hospital Amigo da (riança, IHAC) in fourth step of the "Ten Steps to Successful Breastfeeding"recommends that the professionals help mothers initiate breastfeeding stimulation within the first hour after birth, favoring skin to skin contact immediately after delivery for at least one hour ${ }^{(1)}$.

The Stork Network, established in 2011 by the Ministry of Health,

"consists of a care network aimed at ensuring women the right to reproductive planning and humanized care for pregnancy, childbirth and the puerperium, as well as to the child the right to safe birth and healthy growth and development"(2).

In the childbirth component, it addresses the "evidence-based health care practices, according to the following 1996 World Health Organization document: Good childbirth and childbirth care practices" and, in the puerperal component and comprehensive child health care, the "promotion of breastfeeding"(2).

Thus, among the good practices of attention, skin-to-skin contact (STSC) and breastfeeding stimulation (BF) immediately after birth stand out, which provide important advantages for mother and the newborn (NB) ${ }^{(3-4)}$.

The benefits of STSC for the NB are better first-feeding effectiveness, reduced time to develop effective suction, regulation and maintenance of the NB body temperature, and cardiorespiratory stability. For women, there is a decrease in pain caused by breast engorgement, a feeling of relief, safety and a decrease in anxiety developed during pregnancy. In addition, STSC may result in better breastfeeding rates in the first four months after delivery, longer breastfeeding, better affection and attachment behavior of the mother, bonding, feelings of happiness, love, tranquility and comfort for the woman and the NB. This mix of feelings causes a woman to divert her attention from the discomfort and pain of childbirth to the pleasure of being with her $\mathrm{NB}^{(3-4)}$.

Breastfeeding also includes short- and long-term advantages for newborns and women. Short-term breastfeeding immediately after birth prevents neonatal morbidity and mortality and is associated with longer duration of breastfeeding and longer exclusive breastfeeding. For women, it favors oxytocin release and has a protective effect on maternal mood disorders. In the long term, among the benefits is the better motor development of NBs, as well as the reduced risk of diseases such as diabetes, obesity, gastroenteritis, among others. Women have lactational amenorrhea, decreased risk of developing type 2 diabetes, breast and ovarian cancers, and lose weight faster ${ }^{(5-6)}$.

Breast milk is the food with the highest amount of nutrients and immunological agents that protect the NB of infections, which are the main causes of neonatal mortality. Thus, immediate BF at birth is essential for the NB and prevents $22 \%$ of the neonates from dying of infections as well as it assists in the prevention of bleeding in puerperal women, which is the leading cause of maternal death currently ${ }^{(5,7)}$. BF still brings long-term benefits to the child, such as higher school performance, higher $\mathrm{IQ}$, and longer study time ${ }^{(8)}$.

The combination of STSC and BF has a more effective analgesic effect and recovery after a painful procedure. This was confirmed after evaluating the NB, who had a shorter crying duration, decreased heart rate and increased breastfeeding frequency ${ }^{(6)}$.

The systematic review and meta-analysis of the effect of STSC between mother and child soon after birth showed that the practice had a significantly positive effect on success and duration of first breastfeeding ${ }^{(9)}$.

Given the benefits provided by performing STSC and $\mathrm{BF}$ for women and newborns and the rates presented, this study had the following as its guiding question: How is the skin-to-skin contact practice and breastfeeding stimulation in a university hospital?

The objectives of this study are to determine the prevalence of STSC and breastfeeding immediately after birth and reasons for not performing it; and to identify if women received information about these prenatal practices. It is considered that the findings will allow us to identify the advances in the performance of these practices, as well as opportunities for improvement, and to guide the proposition of evidence-based actions on the means to increase STSC and $\mathrm{BF}$ rates, aiming at the qualification of care.

\section{METHOD}

This study is derived from a research entitled "Care practices implemented during the parturition and birth process". This is a quantitative cross-sectional study, developed at the Obstetric Inpatient Unit (UIO) of a university hospital in a large city in the state of Rio Grande do Sul, a public and university institution, part of the network of University hospitals of the Ministry of Education and linked to the Federal University of Rio Grande do Sul. In 2011, it joined the Stork Network and is certified by the Child Friendly Hospital Initiative. The maternity serves usual-risk pregnant women and is a reference 
for attending high-risk pregnant women. In 2018, it had a mean of 293 births per month, most of them from the Unified Health System (Sistema Único de Saúde, SUS).

The sample calculation considered the proportion of BF in the first hour of life of the NB of $68 \%$, and the difference between the proportions of the NB whose Odds Ratio (OR) is $0.6^{(10)}, 80 \%$ power and $5 \%$ significance level. The sample consisted of 586 women and their NBs.

The sample included parturient women who remained for two hours or more in labor and had their deliveries at the Obstetric Center, with live NBs with a gestational age of 37 weeks or older, according to the Capurro method. Women undergoing elective or emergency caesarean section, cases of fetal death and malformation, cases of twinning and those who were hospitalized for health insurance or self-funding were excluded from the study and from the study from which this study was derived.

The data collection period occurred from February to September 2016, was held after the postpartum woman or her guardian, when underage, signed the Free and Informed Consent Form. Data was obtained from the postpartum women and their NBs medical records and through a questionnaire applied to the postpartum woman after the first 12 hours postpartum. A descriptive analysis of the data was performed using the SPSS software version 18.

As the dependent variable skin-to-skin contact and breastfeeding was considered and, as independent variables, age, race, marital status, schooling, number of prenatal consultations, prenatal care professional, number of pregnancies, parity, type delivery, weight, Apgar score and the information/guidance received.

The larger project was submitted and approved by the Research Committee of the UFRGS School of Nursing (Opinion No. 30187) and the Research Ethics Committee of the institution where the study was developed (Opinion No. 150519). The study met the terms of resolution $466 / 2012$.

\section{QRESULTS}

The sample of this study consisted of 586 postpartum women. Regarding the sociodemographic, prenatal and obstetric characteristics (Table 1), it was found that most were white, aged between 20 and 35 years old, with complete high school, with a partner, performed six or more prenatal consultations, were nulliparous and had the current vaginal delivery.

Regarding the characterization of the NBs, it was found that $98.1 \%$ had a weight greater than or equal to $2500 \mathrm{~g}$, 89.2\% had an Apgar score greater than or equal to seven in the first minute and $99.1 \%$ an Apgar score greater than or equal to seven in the fifth minute.

The following is the data related to receiving STSC information/guidance. Among the interviewees, 265 (45.2\%) reported that they were informed/oriented about this practice at the Obstetric Center Unit (OCU) and the Obstetric Internment Unit (OIU) of the studied institution; 53 (9.0\%) women attended prenatal care; 30 (5.1\%) attended guidance in the media; 23 (3.9\%) were informed by friends and family; 11 (1.9\%) obtained information in the group of prenatal pregnant women; 8 (1.4\%) were oriented at another hospital; $3(0.5 \%)$ obtained information in their vocational training (health area); and $3(0.5 \%)$ already knew this information due to previous pregnancies. Some women reported having obtained STSC information from more than one source.

Regarding the sources of information about breastfeeding during pregnancy, the highest percentage of women (77.1\%) obtained it from the OCU and the OIU of the institution where the research was conducted, followed by prenatal consultation (20\%), friends and family (8.4\%), the media (6.5\%), the pregnant group (2.2\%), another hospital $(1.9 \%)$, health professional training $(0.9 \%)$, previous pregnancy $(0.7 \%)$ and neonatal intensive care unit (0.2\%). It is noteworthy that some women received information from more than one source.

In Graph 1 below, the frequency of the actions related to STSC by the health team is presented, according to the maternal report. It was found that $350(60.1 \%)$ NBs performed STSC with their mothers immediately after delivery and 138 (24.1\%) had STSC after the professional had performed the first care. It is noteworthy that some women reported performing STSC before and after the first care with newborns.

It is to be noted that 186 (32.7\%) of the newborns did not experience STSC at any time. 
Table 1 - Sociodemographic, prenatal and obstetric characteristics of the 586 women admitted to a University Child Frie ndly Hospital. Porto Alegre (RS), 2016

\section{Characteristics}

\section{Sociodemographic}

\section{Maternal age (years old)}

\begin{tabular}{|c|c|c|}
\hline$<19$ years old & 113 & 19.3 \\
\hline 20 to 35 years old & 428 & 73.0 \\
\hline$\geq 36$ years old & 45 & 7.7 \\
\hline \multicolumn{3}{|l|}{ Race/Skin color (self-declared) } \\
\hline Caucasian & 364 & 62.1 \\
\hline Black & 114 & 19.4 \\
\hline Yellow/Brunette/Mulatto & 102 & 17.4 \\
\hline Asian & 05 & 0.9 \\
\hline Indigenous & 01 & 0.2 \\
\hline \multicolumn{3}{|l|}{ Marital status } \\
\hline Had a partner & 522 & 89.1 \\
\hline No partner & 64 & 10.9 \\
\hline \multicolumn{3}{|l|}{ Schooling } \\
\hline Elementary School Incomplete & 112 & 19.1 \\
\hline Complete Elementary School & 75 & 12.8 \\
\hline Incomplete High School & 105 & 17.9 \\
\hline Complete High School & 242 & 41.3 \\
\hline Incomplete Higher Education & 35 & 6.0 \\
\hline Complete Higher Education & 17 & 2.9 \\
\hline \multicolumn{3}{|l|}{ Prenatal } \\
\hline \multicolumn{3}{|c|}{ Number of prenatal consultations* } \\
\hline$<6$ consultations & 130 & 22.5 \\
\hline$\geq 6$ consultations & 449 & 77.5 \\
\hline \multicolumn{3}{|c|}{ Professional who performed the prenatal consultations* } \\
\hline Doctor & 290 & 50.0 \\
\hline Nurse or doctor & 282 & 48.6 \\
\hline Nurse & 08 & 1.4 \\
\hline
\end{tabular}


Table 1 - Cont.

\section{Characteristics}

n

$\%$

\section{Obstetrical}

\section{Number of pregnancies}

\begin{tabular}{lll}
\hline Primigravidas & 298 & 50.9 \\
\hline Multi gestation & 288 & 49.1 \\
\hline Parity & & 59.1 \\
\hline Nulliparous & 346 & 24.7 \\
\hline Primiparous & 145 & 16.2 \\
\hline Multiparous & 95 & 76.6 \\
\hline Type of delivery & & 23.4 \\
\hline Vaginal delivery & 449 & 137 \\
\hline Caesarean section & & 2 \\
\hline
\end{tabular}

Source: Research data, 2016

*Considering only the valid data.

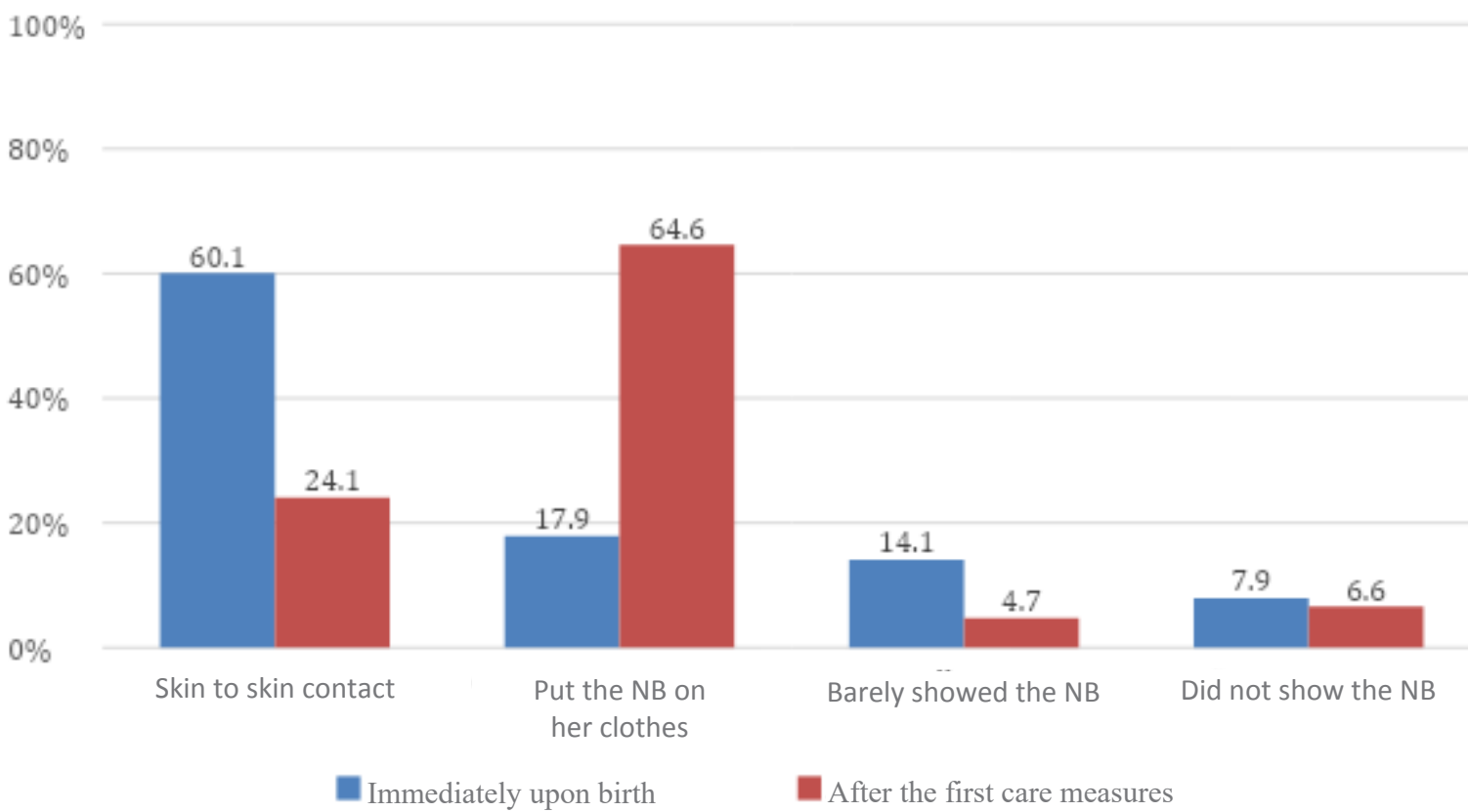

Graph 1 - Frequency of the actions performed by the health team immediately after birth ( $\mathrm{n}=582)$ and after the first care with the NB ( $n=573)$. Porto Alegre (RS), 2016 Source: Research data, 2016

*Considering only the valid data. 
Graph 2 shows the frequency of breastfeeding stimulation immediately after birth and after first NB care. Soon after birth, before the first care was performed, 245 (55.1\%) newborns were not stimulated to BF. After the first care, 343 (69.3\%) were stimulated to BF and, in 240 of them, suction succeeded and 103 did not suck. Non-breastfed infants and women who could not report why there was no stimulation of BF did not enter the frequency calculation.

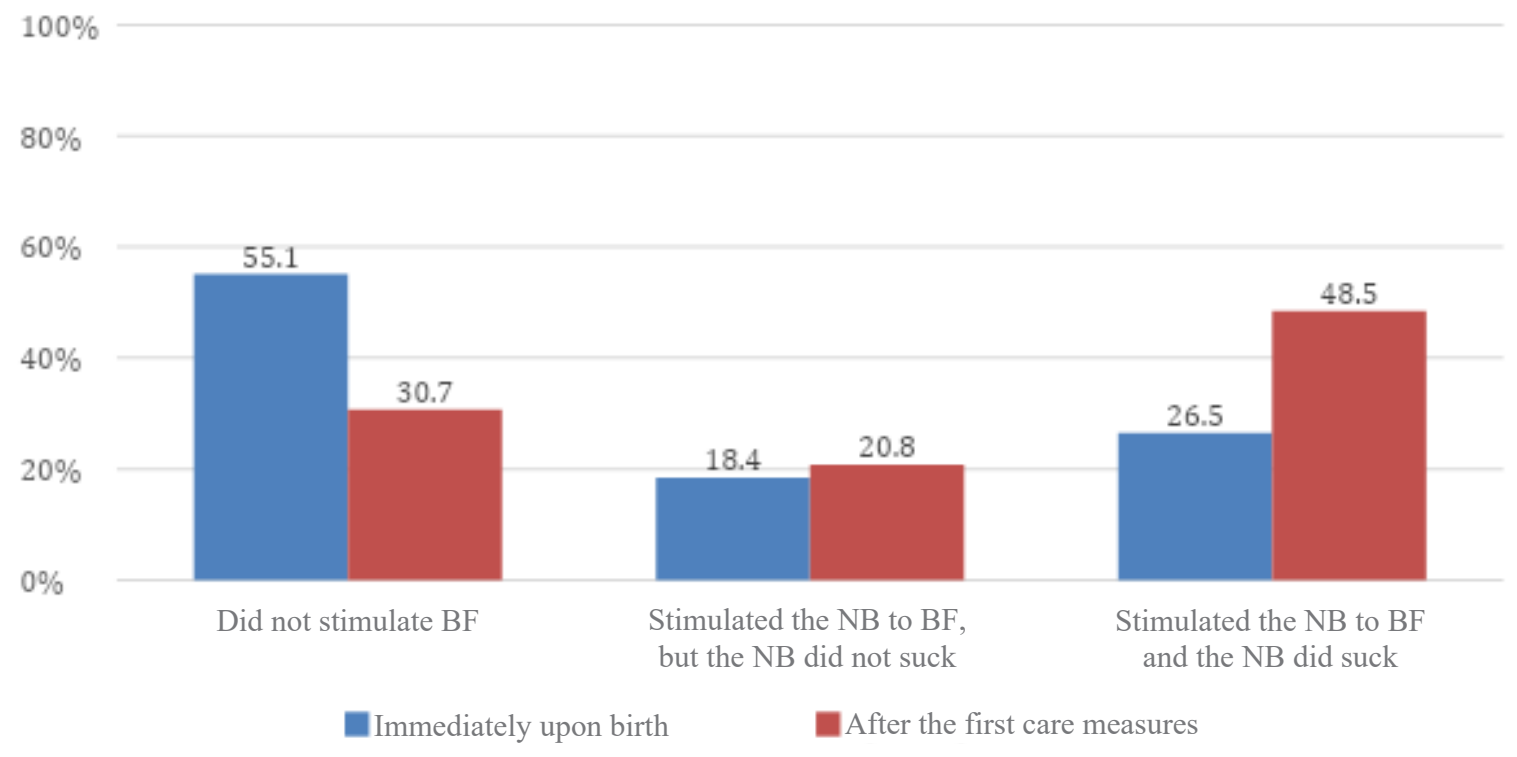

Graph 2 - Frequency of BF stimulation by the health team immediately after birth ( $n=445)$ and after the first NB care $(n=495)$. Porto Alegre (RS), 2016

Source: Research data, 2016.

${ }^{*}$ Considering only the valid data.

When the woman answered that she did not perform STSC and did not have BF stimulated, she was asked why she did not perform these practices. The main reason mentioned by the women for not performing the practice was NB without clinical conditions, i.e., those who needed immediate care at birth, resuscitation maneuvers or who were transferred to the Neonatology Unit. Table 2 shows that 61 (47.7\%) newborns did not perform STSC immediately at birth and 25 (40.3\%) did not perform it after the first care, because the NBs were not in clinical conditions. About BF immediately after birth and after the first care, 190 (79.2\%) and 105 (69.1\%) women, respectively, could not inform what the reason was for not stimulating BF (Table 2). The "others" category includes the following reasons: OCU crowded, professional told the mother not to touch the NB, staff asked to take the NB, inappropriate environment, NB slept, the patient herself put the NB to suck.
After leaving the delivery room, women go through a period in the postpartum recovery room (PPRR). Regarding STSC during this period, it was found that 543 (92.7\%) women remained with their NB. However, 39 (6.6\%) pairs were separated because the baby did not have adequate clinical conditions, one (0.2\%) woman was not clinically well and $3(0.5 \%)$ NBs were separated from the mother to perform the first cares. Regarding BF, in 467 (88.1\%) mother-infant pairs, it was found that BF was stimulated. Among those who were not stimulated (11.9\%), 51 (81\%) NBs showed no interest in breastfeeding, 5 (7.9\%) women had no help putting NB to breastfeed, 3 (4.8\%) women were not in clinical conditions, $3(4.8 \%)$ NBs also had no favorable clinical conditions for BF, and 1 (1.5\%) woman reported that the nurse asked not to stimulate BF until the effect of anesthesia passed. 
Table 2 - Reasons reported by the women for not performing STSC immediately at birth $(n=128)$ and after first NB care $(n=62)$, and of BF immediately after birth $(n=240)$ and after first care with the NB ( $n=152)$. Porto Alegre (RS), 2016

\begin{tabular}{|c|c|c|}
\hline \multicolumn{3}{|c|}{ Skin-to-skin contact } \\
\hline Reasons & $\begin{array}{l}\text { Immediately upon } \\
\text { birth } n=128\end{array}$ & $\begin{array}{c}\text { After the first } \\
\text { care } n=62\end{array}$ \\
\hline NB not in clinical conditions & $61(47.7 \%)$ & $25(40.3 \%)$ \\
\hline Mother not in clinical conditions & $9(7.0 \%)$ & $15(24.2 \%)$ \\
\hline First care and exams & $7(5.5 \%)$ & $8(12.9 \%)$ \\
\hline Not to interfere with the work of the team & $3(2.3 \%)$ & $1(1.6 \%)$ \\
\hline NB stayed with family member & 0 & $4(6.5 \%)$ \\
\hline Did not know & $50(39.1 \%)$ & $10(16.1 \%)$ \\
\hline \multicolumn{3}{|c|}{ Breastfeeding } \\
\hline Reasons & $\begin{array}{l}\text { Immediately upon } \\
\text { birth } n=240\end{array}$ & $\begin{array}{l}\text { After the first } \\
\text { care } n=152\end{array}$ \\
\hline NB not in clinical conditions & $22(9.2 \%)$ & $21(13.8 \%)$ \\
\hline Mother not in clinical conditions & $19(7.9 \%)$ & $19(12.5 \%)$ \\
\hline First care and exams & $2(0.8 \%)$ & $2(1.3 \%)$ \\
\hline Not to interfere with the work of the team & $7(2.9 \%)$ & $3(2.0 \%)$ \\
\hline Did not know & $190(79.2 \%)$ & $105(69.1 \%)$ \\
\hline Others & $2(0.8 \%)$ & $4(2.6 \%)$ \\
\hline
\end{tabular}

Source: Research data, 2016.

*Only the valid data were considered.

\section{DISCUSSION}

In this survey it was found that most women had an appropriate number of prenatal appointments, as recommended by the Ministry of Health, which establishes at least six visits ${ }^{(4)}$. However, it is recommended that these consultations be interspersed between doctor and nurse ${ }^{(4)}$, which in this study occurred with less than half of women. Such a situation may be due to the fact, in many health units, nurses predominantly perform managerial activities; thus, a larger contingent of consultations is performed by the doctor.

Regarding the information obtained by the women about STSC and BF during prenatal care, there are deficiencies since, even with an adequate follow-up, most women did not receive information before STSC (4) . About BF, a research study ${ }^{(11)}$ showed that $55.2 \%$ of the women interviewed had information about BF in the first hour of life of the NB, similarly to the data found in this study. Another study ${ }^{(12)}$ points out that women who receive information about BF are three times more likely to practice exclusive BF. The findings(12) point out that a good prenatal care, with appropriate and consistent guidelines, can influence women's decisions after birth and the continuity of BF.

Prenatal care is the opportune moment for orientation of the woman and her partner. It is essential that information on good practices of childbirth care be addressed during prenatal consultations and that the participation in a group of pregnant women is provided and encouraged, a space in which the exchange of knowledge and experiences is motivated. It is noteworthy that the consultations performed by nurses usually cover the holistic care of women, in addition to health education, and help in the role of women in their pregnancy-puerperal cycle. Nurses are certified and qualified to play the role of caregiver and educator, and health education is paramount for clinical nursing care ${ }^{(13)}$.

STSC and BF are practices that should be encouraged in the first postpartum hour, known as "the Golden Hour". During this period, all the routines should be postponed due to the performance of STSC, which will bring physiological stability benefits to the mother-infant binomial, increasing 
attachment behavior, protecting against negative effects of maternal and child separation, supporting optimal development of the NB and promoting the stimulation of $\mathrm{BF}^{(3-4)}$. Thus, it is recommended that the first contact between mother and child be the STSC immediately after delivery, being provided and made possible by the care team ${ }^{(14)}$.

A study conducted in the Northeast of the country showed that the prevalence of the fourth step of the IHAC was $50.5 \%$, but only $9.3 \%$ of the mother-baby pairs kept performing the fourth step after the first thirty minutes of life ${ }^{(15)}$. This early intimate contact, touching, looking, beginning of the mother-child bond, and stimulating BF is of paramount importance for the newly born life to begin its development in a healthier way ${ }^{(16)}$. The Ministry of Health recommends that $80 \%$ of the births fulfill the prerogatives of the fourth step of the IHAC. Immediately after birth, the NBs should be placed on the mother's lap and, when they show signs, BF should be stimulated ${ }^{(1)}$.

In the present research, the practice of STSC was evaluated before and after the first care. Comparing these data with those of a study conducted in 2012 at the same institution, it was found that there was a $290.2 \%$ increase in STSC before the first care and of $43.4 \%$ after the first care with the $\mathrm{NB}^{(17)}$. The STSC rate is expected to continue to increase as all the newborns in good clinical condition should be placed on their mother's lap immediately at birth. This finding shows that there were advances related to the qualification of care in these four years after the implementation of the Stork Network.

The systematic review data point to the overall prevalence of STSC by income level of the countries and show that this practice after normal delivery was relatively high among high-income, though oscillating. In Denmark, the prevalence of STSC reached a high rate of 96\%, while Japan and Spain reported low rates, with $20 \%$ and 29\%, respectively. Among upper-middle income countries, there was a wide variation in the STSC rate, with 9\% in Mexico and 98\% in Croatia. Brazil is part of this group, with STSC rates ranging from $34.1 \%$ to $41.9 \%$. In middle-low income countries, the STSC rate ranged from $8 \%$ to $74 \%$; in low-income countries, the practice was below $20 \%{ }^{(18)}$.

Findings from a research study ${ }^{(17)}$ developed in 2012 at the institution where this study was conducted showed low rates of STSC and BF, with $15.4 \%$ of the newborns placed on STSC immediately at birth and $16.8 \%$ after the first care, 23.2\% stimulated to BF immediately after birth and $57.9 \%$ after the first care.

When women were asked if, after the care, the NB returned to her lap to continue performing STSC, the vast majority responded that the NBs returned but were placed on their clothing, an action not characterized as STSC. This situation was also evidenced in other studies since the professionals did not favor that the STSC was performed properly, as they used surgical fields to protect the child from heat loss, and the maternal physiology and the contact of the NB with the mother makes for the NB to warm up and maintain body temperature ${ }^{(14)}$.

The main reasons for not performing STSC before and after the first care mentioned by the women in this study were the unfavorable clinical conditions of the mother and/or baby, reaffirming what was presented in the previous study in $2012^{(17)}$, findings that differ from another research ${ }^{(14)}$, in which the reason would be at the request of the mother and due to the performance of the first cares. It is believed that a justification for not promoting STSC may be compliance with institutional routines, lack of knowledge on the part of the professionals, or even a shortage of human resources, which undoubtedly is a limiting factor for the implementation of good practices.

Regarding BF, in 2011, a survey was conducted in an IHAC-certified hospital that found that $31 \%$ of the NBs were breastfed within the first hour of life ${ }^{(11)}$; in the present study, $44.9 \%$ of the NBs were encouraged to breastfeed immediately at birth. In 2012, a similar survey was conducted at the same hospital as this survey, and a $93.5 \%$ increase in BF stimulation was observed immediately after birth, and of $19.5 \%$ after the first care, showing positive variations ${ }^{(17)}$. This finding shows that there have been improvements in the care practice; as a result, it is believed that there are margins for further progress in this area and the realization of good practices.

Regarding the reasons for not stimulating $\mathrm{BF}$, the research shows the health problems of the NB, such as respiratory distress; maternal health problems such as preeclampsia and delay in the rapid anti-HIV test result ${ }^{(11)}$. The reasons found in this research include the unfavorable clinical situation of mother and baby, being the same reasons as the study conducted in 2012 in this institution ${ }^{(17)}$. However, a disturbing fact is that some women could not inform the reason for the non-occurrence of this practice. This situation indicates a possible communication failure between health team and user. It is essential that the parturient be informed about the issues surrounding her and the baby's care, reinforcing the relevance of health education.

It should be noted that the rates of mother and baby joint accommodation in the postpartum recovery room and $\mathrm{BF}$ stimulation had a significant result in the current study. For BF to be effective, women need the help of the health professionals, who must be technically and scientifically prepared for the encouragement and protection of 
the mother-baby pair ${ }^{(16)}$. In a study at the same institution, conducted in 2012, the joint accommodation of mother and NB in the PPRR had an insignificant increase of $5.6 \%$, and $\mathrm{BF}$ in the PPRR had an increase of $21.7 \%{ }^{(17)}$. To ensure the humanization of care, so that it is effective and consistent with the strategies of the Stork Network and the IHAC, it is necessary to raise professional awareness about the benefits of the practice for the mother and the NB.

Concurrently analyzing the practices, it is noteworthy that immediate and simultaneous BF with STSC has benefits, such as decreased bleeding, due to the release of endogenous oxytocin ${ }^{(19)}$. A cohort study shows that women who did not undergo STSC and BF soon after delivery were twice as likely to develop postpartum hemorrhage. Oxytocin plays a key role in postpartum uterine contraction to prevent bleeding, and STSC assists in adapting the NB to extrauterine life ${ }^{(5)}$.

\section{口CONCLUSIONS}

It was found that $60.1 \%$ of the newborns in this study performed the STSC and that $44.9 \%$ were breastfed immediately at birth; however, these practices did not reach the percentage recommended by the Child Friendly Hospital Initiative and by the $\mathrm{MoH}$. The women need information about the benefits of STSC and BF since prenatal so that, at birth, these practices make sense to women. We found that women were informed about the good practices during pregnancy, but most of these women received the information only in the obstetric center and obstetric hospitalization units of the studied institution; only a small number of women reported discussing the issue at prenatal consultations.

The most prevalent reason for not performing the STSC, both immediately after birth and after the first care, was the fact that the NB was not in good clinical conditions, which may justify the rates found, since the research was conducted in a reference hospital for the care of high-risk pregnant women. One fact that drew attention was a significant number of women who could not report the reason for not performing the good practices, which may characterize a deficiency in communication between the health team and puerperal woman.

It is considered essential that the entire health team be involved, supporting and enabling the execution of evidence-based practices in childbirth and birth care, with a view to advances in care indicators, especially in STSC and $\mathrm{BF}$ stimulation. Thus, in this study it was verified that the findings point to opportunities for improvement regarding the performance of these practices.
A possible limitation of the study was not knowing how long the first care took, since these data were reported by the women. One suggestion is to conduct new studies in order to know the point of view of the health professionals about the performance of STSC and BF immediately after birth.

\section{DEFERENCES}

1. Ministério da Saúde (BR) [Internet]. Brasília, DF: Ministério da Saúde; (20132019 [citado 2019 fev 10]. Saúde da criança: 0 que é, cuidados, políticas, vacinação, aleitamento; [approx. 1 screen]. Available from: http://www.saude. gov.br/saude-de-a-z/crianca

2. Ministry of Health (BR). Portaria no 1.459, de 24 de junho de 2011. Institui, no âmbito do Sistema Único de Saúde - SUS - a Rede Cegonha. Brasília, DF, 2011 [cited 2019 Feb 10]. Available from: http://bvsms.saude.gov.br/bvs/ saudelegis/gm/2011/prt1459_24_06_2011.html

3. Kologeski TK, Strapasson MR, Schneider V, Renosto JM. Contato pele a pele do recém-nascido com sua mãe na perspectiva da equipe multiprofissional. Rev Enferm UFPE. 2017 [cited 2019 Feb 10];11(1):94-101. Available from: https:// periodicos.ufpe.br/revistas/revistaenfermagem/article/download/11882/14341

4. D'Artibale EF, Bercini LO. Early contact and breastfeeding: meanings and experiences. Texto Contexto Enferm. 2014;23(1):109-17. doi: https://doi. org/10.1590/50104-07072014000100013

5. Oddy WH. Breastfeeding in the first hour of life protects against neonatal mortality. J Pediatr. 2013;89(2):109-11. doi: https://doi.org/10.1016/j.jped. 2013.03.012

6. Leite MFFS, Barbosa PA, Olivindo DDF, Ximenes VL. Promoção do aleitamento materno na primeira hora de vida do recém-nascido por profissionais da enfermagem. Arq Cienc Saúde UNIPAR. 2016;20(2):137-43. doi: https://doi. org/10.25110/arqsaude.v20i2.2016.5386

7. Saxton A, Fahy K, Holfe M, Skinner V, Hastie C. Does skin-to-skin contact and breast feeding at birth affect the rate of primary postpartum haemorrhage: results of a cohort study. Midwifery. 2015;31(11):1110-7. doi: https://doi. org/10.1016/j.midw.2015.07.008

8. Victora $C_{G}$, Horta BL, Mola $C L$, Quevedo L, Pinheiro RT, Denise PG, et al. Association between breastfeeding and intelligence, educational attainment, and income at 30 years of age: a prospective birth cohort study from Brazil. Lancet Glob Health. 2015;3(4):e199-205. doi: https://doi.org/10.1016/S2214109x(15)70002-1

9. Karimi FZ, Sadeghi R, Saghooni NM, Khadivzadeh T. The effect of mother-infant skin to skin contact on success and duration of first breastfeeding: a systematic review and meta-analysis. Taiwan J Obstet Gynecol. 2019;58(1):1-9. doi: https://doi.org/10.1016/j.jog.2018.11.002

10. Vogt SE, Silva KS, Dias MAB. Comparison of childbirth care models in public hospitals, Brazil. Rev Saúde Pública. 2014;48(2):304-13. doi: https://doi. org/10.1590/S0034-8910.2014048004633

11. Belo MNM, Azevedo PTACC, Belo MPM, Serva VMSBD, Batista Filho M, Figueiroa $J N$, et al. Aleitamento materno na primeira hora de vida em um Hospital Amigo da Criança: prevalência, fatores associados e razões para sua não ocorrência. Rev Bras Saúde Mater Infant. 2014;14(1):65-72. doi: https://doi.org/10.1590/ S1519-38292014000100006 
12. Tewabe T, Mandesh A, Gualu T, Alem G, Mekuria G, Zeleke H. Exclusive breastfeeding practice and associated factores among mothers in Motta town, East Gojjam zone, Amhara Regional State, Ethiopia, 2015: a cross-sectional study. Int Breastfeed J. 2017;12:12. doi: https://doi.org/10.1186/s13006-017-0103-3

13. Guerreiro EM, Rodrigues DP, Queiroz ABA, Ferreira MA. Educação em saúde no ciclo gravídico-puerperal: sentidos atribuídos por puérperas. Rev Bras Enferm. 2014 Fev; 67(1):13-21. doi: https://doi.org/10.5935/0034-7167.20140001

14. Santos LM, Silva JCR, Carvalho ESS, Carneiro AJS, Santana RCB, Fonseca MCC. Vivenciando 0 contato pele a pele com o recém-nascido no pós-parto como um ato mecânico. Rev Bras Enferm. 2014;67(2):202-7. doi: https://doi. org/10.5935/0034-7167.20140026

15. Sampaio ARR, Bousquat A, Barros C. Skin-to-skin contact at birth: a challenge for promoting breastfeeding in a "Baby Friendly" public maternity hospital in Northeast Brazil. Epidemiol Serv Saúde. 2016 [cited 2019 Feb 10];25(2):28190. Available from: http://www.scielo.br/pdf/ress/v25n2/en_2237-9622ress-25-02-00281.pdf
16. Antunes MB, Demitto MO, Soares LG, Radovanovic CAT, Higarashi IH, Ichisato SMT, et al. Amamentação na primeira hora de vida: conhecimento e prática da equipe multiprofissional. Av Enferm. 2017;35(1):19-29. doi: https://doi. org/10.15446/av.enferm.v35n1.43682

17. Chaiben MO. Contato pele a pele e amamentação na primeira hora de vida em um hospital amigo da criança do sul do Brasil [monografia]. Porto Alegre (RS): Universidade Federal do Rio Grande do Sul; 2012 [cited 2019 Feb 10]. Available from: https://lume.ufrgs.br/handle/10183/69739

18. Abdulghani N, Edvardsson K, Amir LH. Worldwide prevalence of motherinfant skin-to-skin contact after vaginal birth: a systematic review. PLOS ONE. 2018;13(10):e0205696. doi: https://doi.org/10.1371/journal.pone.0205696

19. Saxton A, Fahy K, Hastie C. Effects of skin-to-skin contact and breastfeeding at birth on the incidence of PPH: a physiologically based theory. Women Birth. 2014;27(4):250-3. doi: https://doi.org/10.1016/j.wombi.2014.06.004

\section{- Corresponding author:}

Paola Melo Campos

E-mail: paolacampos11@gmail.com

\section{Associate editors:}

Ana Karina Silva da Rocha Tanaka 